\title{
Stigma in Mental Illness: Relative's Perspective
}

\author{
Adhikari SR \\ 1. Assoc. Professor, Department of Psychiatry, Chitwan medical College, Bharatpur
}

E-mail *Corresponding author: shailendra_adhikary@hotmail.com

\begin{abstract}
Introduction: Stigma is an important determinant in mental illness, which determines awareness, symptom recognition and treatment adherence. It is an important factor due to which relatives of patients with psychiatric disorders decide treatment and further evaluation. Materials and Methods: This is cross-sectional retrospective study done at medical college. Valid and standardized rating scales along with socio-demographic profile were used to assess perception, awareness and attitude regarding stigma against mental illness among relatives of patients who have mental illness. Results: Most family members did not perceive themselves as being avoided by others because of their relative's hospitalization, half reported concealing the hospitalization at least to some degree. Both the characteristics of the mental illness (the stigmatizing mark) and the social characteristics of the family were significantly related to levels of family stigma. Care givers whose relative had experienced an episode of illness within the past 6 months reported greater avoidance by others. Conclusion: Stigma experienced by relatives is pervasive and everlasting. It deeply affects emotional, social and occupational aspects of care giver also which leads to concealment of their patient's illness, which have long term detrimental situations and non-compliance of medications.
\end{abstract}

Keywords: stigma, mental illness, care givers, attitude, perception

\section{INTRODUCTION}

Stigma against mental illness cut across all age, religion, ethnic origin or socio-economic status. Relatives or care givers of patients with mental illness experience same kinds of stigma as experienced by patients. Studies on psychiatric stigma have often focused on public attitudes and their perception of patients with mental illness. These collective attitudes vary in their impact on individuals, and stigma is ultimately an inter-subjective experience, they provide at least an approximate guide to how stigma causes difficulties to individuals with mental illness 1. Understanding relative's subjective experiences of stigma attunes us to what is at stake in their lived local worlds (everyday interpersonal transactions with other relatives, neighbors and other people) while they are with patients with mental illness ${ }^{2}$. This kind of stigma endured by family members and care givers is also called "Courtesy stigma" as described for the first time by Goffman in 19633. This type of stigma is detrimental to care givers and patients as well in recovery process of illness, social adjustment, employment and treatment adherence.

Most of the studies and research works in stigmas have been focused on patients as well as general public attitudes including media depiction of mental illness. Very few studies have been done regarding stigma endured by care givers (i.e. courtesy stigma). This study will try to explore stigma related experiences suffered by care givers. This type of study has been done for the first time in the context of Nepal.

MATERIAL AND METHOD

\section{Study Design:}


This was a naturalistic prospective study of patients who were admitted in the in-patient unit of medical college psychiatry department. Patients were assessed by qualified psychiatrists; full history and mental state examinations were done after admissions of the patients. Diagnosis was made according to ICD-10 ${ }^{4}$ assessments were done accordingly. Inclusion and exclusion criteria:

Relatives or care givers of patients who were willing to participate in the study and gave consent. Relatives who refused to give consent were not given questionnaire regarding evaluation forms.

\section{Ethical issues:}

Apart from informed consent from relatives, ethical guidelines for biomedical research on human subjects by Nepal Health Research Council (NHRC) were also adhered to, in addition to principles enunciated in the "declaration of Helsinki".

\section{Sample size:}

Sixty seven relatives were evaluated after their consent. Fourteen refused to participate in the study citing their personal reasons (which they did not elaborate). So remaining 53 care givers participated in the study. They were evaluated during 2 months of study and forms were given at the end of their patient's discharge. Along with written sample, their verbal interviews were also taken for their feedback of their ward admission satisfaction (those who refused for the study were also interviewed for the feedback).

\section{Assessment:}

Demographic form: This form collected demographic variable- age, gender, educational level, marital status and occupation.

Self-stigma of Mental Illness Scale (SSMIS) ${ }^{5}$ was used. It is a 40 item scale which is of selfcompletion type by care givers. It is an exploratory tool that covered stigma in areas of work, family relationship, social relationship and advocacy and medical treatment. The tool was grouped as

1. Work (designated as worked related stigma $=$ WRS)

2. Family relationship (emotional reactions $=\mathrm{ER}$ )

3. Social relationship (negative experience $=\mathrm{NE}$ )

4. Medical treatment (concealment $=\mathrm{C}$ )

This scale has internal consistency for subscales range $\alpha=0.72$ to $\alpha=0.91$. Test- retest reliability for subscales ranged from $0.68-0.82$.
Relative of each patient gave informed consent and participated voluntarily and anonymously. Because of practical difficulties of administering a protracted questionnaire at the acute in-patient psychiatry ward, a shortened 23-item version containing salient domain of stigma was applied. It was back to back translated to Nepali language which was made simple and understandable to care givers. Adequate time was given while patient's relatives completed the questionnaire form. Assistants were provided to care givers and participants were encouraged to for clarifications throughout the data collection process. Questionnaire variables were measured by "yes/no" answers if participants actually experienced stigma and "don't know" if they were not sure. Four questions had multiple answers; last question had been related to care giver's "sad and negative" experiences regarding family member having mental illness- their subjective experiences were sought.

\section{Statistical Analysis:}

Statistical analysis was performed with SPSS program (version 12). Data interpretation was done along with mean, standard deviation. Chi-Square Test was used for assessing the statistical significance of the associations between the variables.

\section{RESULT}

Results have been given in 3 tables. Table 1 shows various socio-demographic profiles of patients. Of 54 Reponses, 33 were males whereas 21 were female. Table 2 gives important responses to questions. Questions include "Family history of mental illness", "Relation of relatives to patients", "Duration of illness in patients" and others. Nearly half of the care givers (21 out of 54) replied that they have family history of mental illness. Majority of patients have duration of illness more than one year (27 out of 54). More than two thirds of patients were care giver's sons $=27$ and daughters $=14$. Table 3 shows various questions response given by care givers. There are 20 questions with response of "Yes", "Don't know/can't say" and "No". Details are given in the table and discussed in discussion and conclusion section of the article. 
Table 1: Socio-demographic profile of relatives who participated in stigma evaluation

\begin{tabular}{|c|c|c|}
\hline TOTAL $=54$ & $\begin{array}{l}\text { FEMALE } \\
(\mathrm{N}=21)\end{array}$ & $\begin{array}{l}\text { MALE } \\
(\mathrm{N}=33)\end{array}$ \\
\hline \multicolumn{3}{|l|}{ Age } \\
\hline $10-19$ years & 4 & 5 \\
\hline 20-29 years & 5 & 9 \\
\hline 30-39 years & 6 & 11 \\
\hline 40-49 years & 3 & 5 \\
\hline 50-59 years & 3 & 3 \\
\hline \multicolumn{3}{|l|}{$\underline{\text { Religion }}$} \\
\hline Hindu & 19 & 25 \\
\hline Buddhist & 0 & 4 \\
\hline Muslim & 0 & 1 \\
\hline Christian & 2 & 3 \\
\hline \multicolumn{3}{|l|}{ Education } \\
\hline Illiterate & 6 & 4 \\
\hline Primary & 3 & 7 \\
\hline Middle & 1 & 5 \\
\hline High School & 6 & 9 \\
\hline Intermediate & 1 & 4 \\
\hline Graduate & 4 & 3 \\
\hline $\begin{array}{l}\text { Post } \\
\text { graduate }\end{array}$ & 0 & 1 \\
\hline $\begin{array}{l}\text { Types of } \\
\text { Family }\end{array}$ & & \\
\hline $\begin{array}{l}\text { Joint } \\
\text { Nuclear }\end{array}$ & $\begin{array}{l}7 \\
14\end{array}$ & $\begin{array}{l}19 \\
14\end{array}$ \\
\hline
\end{tabular}

TABLE 2. comparing various responses of relatives (regarding stigma) whose patients were admitted

\begin{tabular}{|c|}
\hline $\begin{array}{l}\text { VARIOUS RESPONSES } \\
\text { [M-male; F=female] }\end{array}$ \\
\hline Family history of mental illness \\
\hline YES= 21 [M=11 / F=10]; \\
\hline $\mathrm{NO}=33[\mathrm{M}=22 / \mathrm{F}=11]$ \\
\hline Relation of relatives to patients \\
\hline SON / DAUGHTER = 27/14 \\
\hline FATHER / MOTHER = 2 / 2 \\
\hline HUSBAND / WIFE = 2 / 3 \\
\hline FRIENDS $\quad=1 / 1$ \\
\hline NEIGHBORS \\
\hline Duration of illness in patients \\
\hline $\begin{array}{l}\text { A)Less than six months }=19[\mathrm{M}=14 \text {; } \\
\mathrm{F}=5]\end{array}$ \\
\hline B) Six months to one year= $7[M=4$; \\
\hline
\end{tabular}

\begin{tabular}{|l|}
\hline $\mathrm{F}=3]$ \\
C)More than one year= $27[\mathrm{M}=15$ / $\mathrm{F}=$ \\
13] \\
Where did you take your relatives \\
when he/she had mental illness? \\
A)Traditional healers $=9[\mathrm{M}=5$ / F=4] \\
B)Hospitals-psychiatric \\
department=44 [M=28 / F=17] \\
C)Others-Ayurveda / Unnani \\
etc.... =0 \\
What do you think we should do with \\
mental illness? \\
A)Shown to traditional healers=13 \\
[M=5 / F=7] \\
B)Keep in jail=0 \\
C)Hospitalized=36 [M=26 / F=10] \\
D)Don't do anything/ keep at home=5 \\
[M=2 / F=4]
\end{tabular}

Table 3: Relatives' responses in various stigma related questionnaire $[\mathrm{f}=\mathrm{female}$; m=male]

\begin{tabular}{|c|c|c|c|c|}
\hline $\begin{array}{l}\text { S. } \\
\text { No. }\end{array}$ & $\begin{array}{l}\text { QUESTIONNAIRE } \\
\mathrm{C}=\text { concealment; } \mathrm{NE}=\text { negative } \\
\text { experience; } \mathrm{WR}=\text { work related } \\
\text { stigma; } \mathrm{ER}=\mathrm{emotional} \text { reaction }\end{array}$ & Yes & $\begin{array}{l}\text { Don't } \\
\text { know/ } \\
\text { can't } \\
\text { say }\end{array}$ & No \\
\hline 1. & $\begin{array}{l}\text { Do you try your best to hide the } \\
\text { fact that your family member has } \\
\text { mental illness?(C) }\end{array}$ & $\begin{array}{l}f=5 \\
m=8\end{array}$ & $\begin{array}{l}\mathrm{f}=2 \\
\mathrm{~m}=1\end{array}$ & $\begin{array}{l}f=14 \\
m=24\end{array}$ \\
\hline 2 & $\begin{array}{l}\text { Do you wait until you know a } \\
\text { person well before you tell them } \\
\text { about your family's mental } \\
\text { illness?(C) }\end{array}$ & $\begin{array}{l}f=10 \\
m=17\end{array}$ & $\begin{array}{l}f=5 \\
m=1\end{array}$ & $\begin{array}{l}\mathrm{f}=6 \\
\mathrm{~m}=15\end{array}$ \\
\hline 3 & $\begin{array}{l}\text { Do you try to hide mental illness of } \\
\text { your family members with health } \\
\text { professionals?(C) }\end{array}$ & $\begin{array}{l}f=5 \\
m=3\end{array}$ & $\begin{array}{l}\mathrm{f}=2 \\
\mathrm{~m}=4\end{array}$ & $\begin{array}{l}f=14 \\
m=26\end{array}$ \\
\hline 4 & $\begin{array}{l}\text { Do you feel being } \\
\text { humiliated/discriminated in } \\
\text { society due to mental illness in the } \\
\text { family?(NE) }\end{array}$ & $\begin{array}{l}\mathrm{f}=5 \\
\mathrm{~m}=9\end{array}$ & $\begin{array}{l}\mathrm{f}=1 \\
\mathrm{~m}=2\end{array}$ & $\begin{array}{l}\mathrm{f}=15 \\
\mathrm{~m}=22\end{array}$ \\
\hline 5 & $\begin{array}{l}\text { Have you been verbally abused by } \\
\text { other people due to mental illness } \\
\text { of your family members? (NE) }\end{array}$ & $\begin{array}{l}\mathrm{f}=4 \\
\mathrm{~m}=9\end{array}$ & $\begin{array}{l}\mathrm{f}=2 \\
\mathrm{~m}=3\end{array}$ & $\begin{array}{l}\mathrm{f}=15 \\
\mathrm{~m}=21\end{array}$ \\
\hline 6 & $\begin{array}{l}\text { Do you feel your family being } \\
\text { financially burdened by mental } \\
\text { illness in the family? (NE) }\end{array}$ & $\begin{array}{l}f=12 \\
m=20\end{array}$ & $\begin{array}{l}\mathrm{f}=5 \\
\mathrm{~m}=1\end{array}$ & $\begin{array}{l}\mathrm{f}=5 \\
\mathrm{~m}=12\end{array}$ \\
\hline 7 & $\begin{array}{l}\text { Have you found neighbors and } \\
\text { other closed relatives being less } \\
\text { supportive due to mental illness in } \\
\text { the family? (NE) }\end{array}$ & $\begin{array}{l}\mathrm{f}=7 \\
\mathrm{~m}=14\end{array}$ & $\begin{array}{l}\mathrm{f}=5 \\
\mathrm{~m}=3\end{array}$ & $\begin{array}{l}\mathrm{f}=9 \\
\mathrm{~m}=16\end{array}$ \\
\hline 8 & $\begin{array}{l}\text { Do you feel that media is } \\
\text { publishing/broadcasting negative } \\
\text { reports regarding mental illness? } \\
\text { (NE) }\end{array}$ & $\begin{array}{l}\mathrm{f}=1 \\
\mathrm{~m}=4\end{array}$ & $\begin{array}{l}\mathrm{f}=7 \\
\mathrm{~m}=10\end{array}$ & $\begin{array}{l}\mathrm{f}=13 \\
\mathrm{~m}=19\end{array}$ \\
\hline 9 & $\begin{array}{l}\text { Do you think people with mental } \\
\text { disorders are dangerous? (NE) }\end{array}$ & $\begin{array}{l}\mathrm{f}=10 \\
\mathrm{~m}=13\end{array}$ & $\begin{array}{l}f=2 \\
m=10\end{array}$ & $\begin{array}{l}f=9 \\
m=10\end{array}$ \\
\hline 10 & $\begin{array}{l}\text { Do you think people with mental } \\
\text { disorders are violent? (NE) }\end{array}$ & $\begin{array}{l}\mathrm{f}=5 ; \mathrm{m} \\
=9\end{array}$ & $\begin{array}{l}f=6 ; m= \\
9\end{array}$ & $\begin{array}{l}\mathrm{f}=10 ; \mathrm{m} \\
=15\end{array}$ \\
\hline
\end{tabular}




\begin{tabular}{|c|c|c|c|c|}
\hline 11 & $\begin{array}{l}\text { Do you feel that people with } \\
\text { mental disorders should be treated } \\
\text { as criminals? (NE) }\end{array}$ & $\begin{array}{l}\mathrm{f}=0 ; \mathrm{m} \\
=0\end{array}$ & $\begin{array}{l}\mathrm{f}=1 \\
\mathrm{~m}=9\end{array}$ & $\begin{array}{l}\mathrm{f}=20 \\
\mathrm{~m}=24\end{array}$ \\
\hline 12 & $\begin{array}{l}\text { Do you experience that you are } \\
\text { receiving adequate true } \\
\text { information about mental illness? } \\
\text { (NE) }\end{array}$ & $\begin{array}{l}\mathrm{f}=9 \\
\mathrm{~m}=12\end{array}$ & $\begin{array}{l}\mathrm{f}=2 \\
\mathrm{~m}=6\end{array}$ & $\begin{array}{l}\mathrm{f}=10 \\
\mathrm{~m}=15\end{array}$ \\
\hline 13 & $\begin{array}{l}\text { Do you think voluntary } \\
\text { organizations are doing adequate } \\
\text { work in the field of mental } \\
\text { disorders? (NE) }\end{array}$ & $\begin{array}{l}\mathrm{f}=5 \\
\mathrm{~m}=11\end{array}$ & $\begin{array}{l}\mathrm{f}=3 \\
\mathrm{~m}=7\end{array}$ & $\begin{array}{l}\mathrm{f}=13 \\
\mathrm{~m}=15\end{array}$ \\
\hline 14 & $\begin{array}{l}\text { Do you feel health organizations } \\
\text { are giving less priority to mental } \\
\text { disorders as compared to other } \\
\text { disorders? (NE) }\end{array}$ & $\begin{array}{l}\mathrm{f}=7 \\
\mathrm{~m}=13\end{array}$ & $\begin{array}{l}f=1 \\
m=6\end{array}$ & $\begin{array}{l}\mathrm{f}=13 \\
\mathrm{~m}=14\end{array}$ \\
\hline 15 & $\begin{array}{l}\text { Do you think your occupation } \\
\text { being interfered due to your } \\
\text { family's mental illness?(WR) }\end{array}$ & $\begin{array}{l}\mathrm{f}=12 \\
\mathrm{~m}=18\end{array}$ & $\begin{array}{l}\mathrm{f}=1 \\
\mathrm{~m}=1\end{array}$ & $\begin{array}{l}\mathrm{f}=8 \\
\mathrm{~m}=14\end{array}$ \\
\hline 16 & $\begin{array}{l}\text { Have you faced problems with } \\
\text { house tenets due to mental illness } \\
\text { of your family members? (WR) }\end{array}$ & $\begin{array}{l}\mathrm{f}=5 \\
\mathrm{~m}=5\end{array}$ & $\begin{array}{l}\mathrm{f}=6 \\
\mathrm{~m}=7\end{array}$ & $\begin{array}{l}\mathrm{f}=10 \\
\mathrm{~m}=21\end{array}$ \\
\hline 17 & $\begin{array}{l}\text { Do you have blamed yourself for } \\
\text { mental illness of your family } \\
\text { members?(ER) }\end{array}$ & $\begin{array}{l}f=2 \\
m=6\end{array}$ & $\begin{array}{l}\mathrm{f}=1 \\
\mathrm{~m}=11\end{array}$ & $\begin{array}{l}\mathrm{f}=18 \\
\mathrm{~m}=16\end{array}$ \\
\hline 18 & $\begin{array}{l}\text { Do you think that there are } \\
\text { adequate laws/rules regarding } \\
\text { mental illness? (ER) }\end{array}$ & $\begin{array}{l}\mathrm{f}=2 \\
\mathrm{~m}=5\end{array}$ & $\begin{array}{l}\mathrm{f}=13 \\
\mathrm{~m}=15\end{array}$ & $\begin{array}{l}\mathrm{f}=6 \\
\mathrm{~m}=13\end{array}$ \\
\hline 19 & $\begin{array}{l}\text { Have you experienced any } \\
\text { symptoms of mental disorders as a } \\
\text { consequence of mental illness of } \\
\text { your family members? (ER) }\end{array}$ & $\begin{array}{l}\mathrm{f}=4 \\
\mathrm{~m}=9\end{array}$ & $\begin{array}{l}\mathrm{f}=4 \\
\mathrm{~m}=5\end{array}$ & $\begin{array}{l}\mathrm{f}=13 \\
\mathrm{~m}=19\end{array}$ \\
\hline 20 & $\begin{array}{l}\text { Do you feel your relationship } \\
\text { strained with other relatives due to } \\
\text { mental illness in your family } \\
\text { members? (ER) }\end{array}$ & $\begin{array}{l}\mathrm{f}=6 \\
\mathrm{~m}=10\end{array}$ & $\begin{array}{l}\mathrm{f}=0 \\
\mathrm{~m}=5\end{array}$ & $\begin{array}{l}\mathrm{f}=15 \\
\mathrm{~m}=18\end{array}$ \\
\hline
\end{tabular}

perpetuation of stigma ${ }^{11}$. While most family members did not perceive themselves as being avoided by others because of their relative's hospitalization(only $16 \%$ relatives reported), many reported concealing the hospitalization at least to some degree, as in many other studies ${ }^{12}$. Both the characteristics of the mental illness (the stigmatizing mark) and the social characteristics of the family are significantly related to levels of family stigma. Family members will conceal mental illness if they do not live with their ill relative, if the relative is female, and if the relative has less severe psychotic symptoms. Family members with more education and whose relative had experienced an episode of illness within the past 6 months reported greater avoidance by others. In similar study as this ${ }^{13}$, $43 \%$ of care givers perceived that most people devalue families with mental disorders. In some studies, $45 \%$ and $49 \%$ (two samples) agreed strongly with the item "Most people look down on families that have a member who is mentally ill living with them". Similarly study done in Germany ${ }^{14}, 15$, nearly $30 \%$ relatives experience discrimination. Forms of discrimination most often cited were

\section{DISCUSSION}

As with similar finding with this study, there are other studies where patient's relatives (parents/care givers/spouse) experience "courtesy stigma". They experience stigma from variety of sources neighbors, communities, media (both audio and visual and internet) and even from other medical fraternities $^{6}, 7$. Stigma includes negative perception, stereotyping, social distancing, labeling, emotional reactions, status $\operatorname{loss}^{8}$, cognitive separating and overall "negative rating" ${ }^{\prime \prime}$. This study also highlights the stigma formation process as described in other studies $^{10}$ especially discrimination which is very detrimental in recovery of patients. In similar to this study, strong stereotype of dangerousness and desire of social distance by care givers are the main reasons for the withdrawal $(22 \%)$, assignment of guilt $(17 \%)$, devaluation $(14 \%)$ and negative reactions $(11 \%)$. Various subjective stigmatization experiences are grouped in table $4^{16}$.

This study has certain limitations. Due to the small number of people questioned, pattern of stigmatizing experiences may not show the complete picture of the stigma experienced by relatives and their ill family member. Since relatives were recruited from ward setting of admitted patients, the generalizability of our findings is limited by the non-random selection of survey participants. The sample was mainly composed of parents, i.e. more than three-quarters were mothers or fathers. Their relationship with the ill person is characterized by responsibility, i.e., they act as the major caretaker, and have a special emotional closeness. It could be argued that the majority of statements reflect this emotional closeness and that parents are particularly susceptible to stigmatization and 
discrimination since they feel responsible for the well-being of their children.

TABLE 4. Subjective stigmatization experiences (by patients and relatives): domains and facets 16

\section{Interpersonal interaction}

Contact with mental health professionals

- Lack of interest

- Inadequate flow of information

- Technical language as a means of excluding relatives

Social exclusion and withdrawal

- Lack of interest;

-curiosity, ridicule, and gossip

- Discriminating comments

- Concealment of illness

Assignment of guilt

Insecurity, lack of knowledge, and fear

Structural discrimination

Poor quality of mental health care

Legislation and laws

Financial burden

Bureaucratic procedures at official authorities

Poor performance of health insurance

Lack of crisis-support facilities

Lack of support for self-help groups

Public images of mental illness

Media representation (mostly negative reports about mental illness)

Association of mental illness with violent and dangerous behavior

Ignorance and lack of information

Unequal acceptance of mental and physical illness

Incomprehensibility of the illness experience

Rejection of mental health facilities in the community

Metaphorical use of word 'schizophrenic'

Lack of support for self-help groups

Access to social roles

Difficult access to work and problems with integration at work

Problems maintaining an existing partnership

Problems with landlords

\section{CONCLUSION}

Stigma experienced by relatives is pervasive and everlasting. It deeply affects emotional, social and occupational aspects of care giver also which leads to concealment of their patient's illness, which have long term detrimental situations and non-compliance of medications. In our social context, patients are mainly taken care of by their relatives, especially parents and spouse. In fact, more than three-quarters care givers in this study were mothers or fathers. Their relationship with the ill person is characterized by responsibility, i.e., they act as the major care taker, and have a special emotional closeness. It could be argued that the majority of statements reflect this emotional closeness and that parents are particularly susceptible to stigmatization and discrimination since they feel responsible for the well-being of their children. So emotional understanding of stigmatization process of care givers is very important in understanding their inner feelings and future attitudes towards patients and the illness process.

Successful treatment and community management of mental illness relies heavily on the involvement of many levels of government, social institutions, clinicians, caregivers, the public at large, consumers, and their families. Successful community reintegration of mental health patients and the acceptance of mental illness as an inescapable element of our social fabric can only be achieved by engaging the public in a true dialogue about the nature of mental illness, their devastating effects on individuals and communities, and the promise of better treatment and rehabilitation alternatives ${ }^{17}$.

An enlightened public, working in unison with professional association and with lobby groups on behalf of persons with mental illness, can leverage national governments and health care organizations to provide equitable access to treatment and to develop legislation against discrimination ${ }^{17}$. Candid exchange of ideas is needed about the causes of stigma and the consequences of stigmatizing attitudes in their mindset. Only the sincere and whole hearted efforts will eventually dispel the stigma associated with mental illness.

\section{REFERENCE}

1. Lee S, TY Lee Margaret, Chiu Marcus YL and Kleinman A. Experience of social stigma by people with schizophrenia in Hong Kong. British J of Psychiatry. 2005; 186; 153-157.

2. Kleinman A \& Kleinman J (1997) Moral transformations of health and suffering in Chinese society. In Morality and Health (Eds. A M Brandt \& P Rozin) pp.101-118. New York: Routledge.

3. Goffman E. Stigma: Notes on the management of spoiled identity. New York: Prentice Hall. Inc.; 1963. 
4. World Health Organization (WHO) (1992) The ICD - 10 classifications of mental and behavioral disorders: Diagnostic criteria for research. Geneva: World Health Organization.

5. Corrigan PW, Watson AC, Barr L: The self-stigma of mental illness: implications for self-esteem and self-efficacy. Journal of Social \& Clinical Psychology 2006; 25:875-884.

6. Wahl OF. Mental health consumers' experience of stigma. Schizophr Bull. 1999; 25 (3):467-78.

7. Schulze B, Angermeyer MC. Subjective experiences of stigma. A focus group study of schizophrenic patients, their relatives and mental health professionals. Evidence Based Mental Health. 2003; Aug; 6(3):96.

8. Anglin DM, Link BG, Phelan JC. Racial differences in stigmatizing attitudes toward people with mental illness. Psychiatric Serv. 2006; Jun; 57 (6):857-62.

9. Eker D. Attitudes toward mental illness: recognition, desired social distance, expected burden and negative influence on mental health among Turkish freshmen. Soc Psychiatry Epidemiology. 1989; May; 24(3):146-50.

10. Link BG, Yang LH, Phelan JC, Collins PY. Measuring mental illness stigma. Schizophrenia Bull. 2004; 30(3):511-41.

11. Phelan JC, Link BG. Fear of people with mental illnesses: the role of personal and impersonal contact and exposure to threat or harm. J Health Soc Behav. 2004; Mar; 45 (1):68-80.

12. Phelan JC, Bromet EJ, Link BG. Psychiatric illness and family stigma. Schizophrenia Bull.1998; 24(1):115-26.

13. Struening EL, Perlick DA, Link BG, Hellmann F, Herman D, Sirey JA. The extent to which caregivers believe most people de- value consumers and their families. Psychiatric Services. 2001; 52:1633-1638.

14. Angermeyer MC, Matschinger $\mathrm{H}$, Holzinger A. Die Belas- tung der Angehörigen psychisch Kranker. Psychiatry Prax. 1997; 24: 215-220

15. Angermeyer MC From intuition to evidencebased anti- stigma interventions. World Psychiatry. 2002; 1:21-22.

16. Angermeyer MC, Schulze B, Dietrich S. Courtesy stigma: a focus group study of relatives of schizophrenia patients. Social Psychiatry Psychiatric Epidemiology 2003; 38:593-602.

17. Arboleda-Flórez J. Considerations on the Stigma of Mental Illness (Guest Editorial) the Canadian Journal of Psychiatry 2003; 48 (10); 645-650. 